\title{
THE STUDENTS' LANGUAGE LEARNING STRATEGIES IN READING AND SPEAKING
}

\author{
Hidayat Al Azmi \\ Dosen Fakultas Tarbiyah IAIN Imam Bonjol Padang \\ e-mail: marvelouseazmi@yahoo.co.id
}

\begin{abstract}
Many types of learning strategies can be used by the language learners to make the learning process running well. However, in the doing the practice the students are identified have limited types of learning strategies and it makes them face many problems in learning. The aims of the study is to find the typical language learning strategies used by the English Department Students in speaking and reading in English. The result of the study showed that the level of the strategies used were still medium. Thus, the students of English Department are suggested to apply many strategies. it also hopes that the teachers are able to train sufficient strategy.
\end{abstract}

\begin{abstract}
Abstrak: Berbagai jenis strategi belajar dapat membantu pembelajar belajar bahasa Inggris. Namun demikian di dalam penerapannya, mahasiswa masih memiliki strategi yang kurang dan menyebabkan mereka mengalami kesulitan dalam belajar. Tujuan dari penelitian ini adalah untuk menemukan jenis strategi belajar yang digunakan mahasiswa Tadris bahasa Inggris di dalam berbicara dan membaca. Temuan penelitian ini menggambarkan tingkat strategi yang digunakan oleh mahasiswa masih sedang. Karena itu, mahasiswa dihapkan dapat menerapkan berbagai strategi. Para dosen juga diharapkan dapat melatih berbagai strategi kepada mahasiswa.
\end{abstract}

Keywords: learning strategies, speaking, reading

\section{INTRODUCTION}

To improve the English skills, language learner need to know, master, and create the language learning strategies. Knowing the types of language learning strategies will give the student same alternative in learning strategies that mostly appropriate to use. Fedderholt (2006: 1) argue that successful language learner make use of different types of learning strategies. Indeed, learning strategies can make a powerful impact to the outcome of language learning. Zainil (2005: 69) also state that nowadays, researcher as well English language teacher and lecturer believe that the strategies play a major role in learning English because the learner attention is not on structural devices anymore but on developing communicative competence.

Teaching English as a foreign language must play a very crucial role to help the language learner to improve the language skills. Like other skills, in reading and speaking the students do not only need to know the various types of learning strategies but they also need guidance from the teacher or lecturer both in recognizing and use the strategies. They need steps and way to use to use the strategies. But, the strategies cannot be applied well if there is no strong drive from the student. In fact, the many findings show that the students participation always determine the success or the failure of the language learning. It may imply that the main purpose of the teaching English in the class is to enable or to help the student to learn independently by using the kinds of learning strategies.

Language learning strategies may exist in all level. A student begins to learn speaking and reading in English from the elementary school, it means that he/ she begins to use learning strategies taught by the teacher. Repetition, imitation, memorization, using chart and games are typical learning strategies used in this level of learning. It is basically the same when the students learn speaking and reading in higher level as like in a university. The college student must learn and to be familiar with the more complicated sentences. Actually, the English college student especially the student of the English Department has been taught and offered the various types of learning strategies in speaking and reading class. 
There are some classifications of learning strategies. They are cognitive, metacognitive and social learning strategies. O'Malley and Chamot (1990) explain that metacognitive learning strategies deal with selfmanagement: setting goals, monitoring and doing self evaluation. Cognitive learning strategies deal with actual information: how to obtain it; differencing meaning from context, using dictionary and grammar books; retaining it through memorization, repetition, Mnemonic trick, and writing things down; and retrieving it. Socio-Affective learning strategies include cooperating with classmate, friends, teacher finding a native speaker to speak English.

Good language learners are not only required to apply the strategies in learning, but they also need to do evaluation, monitor and manage the strategies they are applying. Learning strategies need a process of monitoring to make the strategies keep running, need evaluation to know the achievement of the learning process. Then, they also need management to arise their willingness $t \mathrm{o}$ run the strategies. Good language learner must also aware of the social aspect of learning since learning language aims to enable the learner to communicate successfully.

Due to their position as a candidate of Englis Teacher, The English department are extremely required to master both spoken and written skill of English. Unfortunately, based on the researcher experience and pre observation, there are still many English Department Student (pre-served teacher) at Bung Hatta University have low outcome of English learning especially in reading and speaking. The possible causes are the limitation of learning strategies which are given by the lecturer, the lack of the student creativity and motivation to find their own ways in learning, less management and evaluation in learning and have no strong desire to find persons or parties to collaborate in learning. These make them still be far in finding the most suitable strategies and difficult to find the ways of learning that they need. Then, the strategies often found does not match with condition, interest, ability and the knowledge that the students have. In other words students differ as language learner in part because the differences of ability, motivation or effort, but a major difference lies in their knowledge about and skill in using 'how to learn' techniques that are, learning strategies (Kennedy and Keatly, 2006).

Based on the illustration above, the it is important to set a descriptive study to know the types of learning strategies used by the Students of English Department of Pre-Served Teacher, Faculty of Teacher Training and Education of Bung Hatta University in Speaking and Reading.

\section{LEARNING STRATEGIES}

Learning strategies are described in some ways. Oxford (1994:1) argue that foreign (L2) strategies are specifics action, behavior, steps or technique students use - often consciously - their progress in apprehending, internalizing, and using the L2. Meanwhile, Wenden and Rubin (1987:19) define learning strategies as any set of operation, steps, plans, and routines, used by the learner to facilitate the obtaining, storage, retrieval, and use of information.

\section{Good language Learner}

Rubin and Thomson (1982) say that the learner can be considered good if they have the following criteria:

They must find their own ways of learning, taking charge in their learning; organize information about the language to be learn; are creative; developing a "feel" for the language by experimenting with its grammar and words; make their own opportunities practice in using the language inside or outside the classroom; learn to leave with uncertainty by not getting frustrated and by continuing to talk and listening without understanding every words; use mnemonic and other memory strategies to re call what has been learned; make error work for them and not against them; use linguistics knowledge including the knowledge of their first language in learning the second language; use the contextual cues to help them in comprehension; learn to make an intelligence guess; earn chunks of language as whole and formalize 
routines to help them perform' beyond their competence; learn different types of speech and writing and learn to vary their language according formality of education.

Ellis (1994) also summarizes the results of various "good language leaner studies" into five major aspects successful language learning. The first aspect of the successful of language learning is a concern for language for language form. Researcher found that good language learner treat a the language as a system by making effective cross lingual comparisons, analyzing the target language, and using reference books. Good language learner also pay attention to meaning, searching for it in the L2 data they are exposed to and trying to engage in real communication by seeking out opportunities for natural use. Third, good language learners show active involvement in language learning. Rather than developing dependence upon the teacher, they take charge of their own learning by identifying and pursuing goals and by trying to introduce new topics into conversations. The fourth characteristic concerned their metacognitive awareness of the learning process. Successful language learners are thoughtful and aware of themselves, make conscious decision and follow their preferred learning styles.

Additionally, in the recent finding, Keatly and Kennedy (2006) also formulate the criteria of good language learner. First, they state that good language learners are able to identify the best strategies for a specifics task; poor learners have difficulty in choosing the best strategies for a specific task. Second, good learners are flexible in their approach and adopt a different strategy, if the first one doesn't work; poor learners have limited variety of strategies in their repertoires and stay with first strategy they have chosen even when it doesn't work. Third, good learners have confidence in their learning ability; poor learners lack confidence in their learning ability. Finally, good learners expect to succeed, fulfill their expectation, and mere motivated; poor learners expect to do poorly, fulfill their expectation and lose the motivation.
To be a good language learner a student must have a strong will and should be creative to find his or her learning strategies. Willing to try new strategies is the key of a good language learner to get the outcome of language learning. During their effort of try the new strategies, means that they are in the process of finding the most suitable strategies that really fit their potency and ability.

\section{Factors that influence the Choice of Language Learning Strategies.}

These are some factors that make the student differ in choosing their own leaning strategies. Oxford (1994:1) synthesizes existing research on how the following factors influence the choice of strategies used among students learning a second language.

(a) Motivation

More motivated tended to use more strategies than less motivated student, and the particular reason for studying the language (motivational orientation, especially related to career field) was important in the choice of strategies.

(b) Gender

Females reported greater overall strategy use than males in many studies (although sometimes males surpassed females in the use of particular strategy).

(c) Cultural Background

Rote memorization and other forms of memorization were more prevalent among some Asian student than students from other cultural background. Certain other cultures also appeared to encourage this strategy among learner.

(d) Attitudes and Belief

These were reported to a profound effect on the strategies learners choose, with negative attitudes and beliefs often causing poor strategy use or lack of orchestration of strategies.

(e) Types of Task

The natures of the task help determine the strategies naturally employed to carry out the task.

(f) Age and L2 stage

Students of different ages and stages of L2 learning use different strategies, with 
certain strategies often being employed by older or more advanced students.

(g) Learning Style

Learning style (general approach to language learning) often determine the choice L2 learning strategies. For example, analytic-styles students preferred strategies such as contrastive analysis, rule-learning, and dissecting words and phrase, while global student use strategies to find meaning (guessing, scanning, predicting) and to converse without knowing all the words (paraphrasing, gesturing .

(h) Tolerance of Ambiguity

Students who are more tolerant of ambiguity use significantly different learning strategies in some instances than did the students who were less tolerant of ambiguity.

\section{Classification of Learning Strategies}

Wenden and rubin (1987: 23) classify the language learning strategies in to several categories:

\section{a. Cognitive Learning Strategies.}

The types of this learning strategies may be vary.

1. Clarification/ verification which refer to those strategies which learner use to verify or clarify their understanding of the new language. In the process of creating and confirming rules, in any languages, they may seek confirmation of their understanding of the language, they may ask for validation of their production of words, phrases or sentences is consistent with the new languages.

2. Guessing/ inductive differencing refers to strategies which uses previously obtain linguistic or conceptual knowledge to derive explicit hypotheses about the linguistics form, semantic meaning or speaker intention.

3. Deductive which is a problem solving strategy in which the learner looks for and use general rule in approaching the foreign or the second language.

4. Practice which refers to strategy that contribute to the storage and retrieval of language while focusing on the accuracy of usage.
5. Memorization also refers to strategies which focus on the storage and retrieval of language; therefore some of the strategies such as drill, repetition, used for practice are the same as the memorizing strategies.

6. Monitoring refers to strategies in which the learner notice errors (both linguistics and communicative), observe how a massage is received and interpreted by the addressee

\section{b. Metacognitive Learning Strategies}

Metacognitive strategies are used to oversee, regulate, or self-language learning. Wended in Wenden and Rubin (1987:25) Examine how learner regulate their learning by planning, monitoring and learning their learning activities. As addition, O'Malley in Wenden and Rubin (1987: 25) provide an extended list of planning strategies: selfmanagement, advance preparation, advance organizer, directed attention, selective attention, and delayed production.

\section{c. Communication Strategies}

From the point of view of the learning process, communication strategies are very important because they allow the learner to remain in the conversation. By continual exposure to natural conversation learner also learn (1) through opportunity to hear more of the target language, and (2) through opportunities to produce new utterance and test their knowledge.

\section{d.Social Strategies}

Social Strategies are those activities learner engage in which afford them opportunities to exposed to practice their knowledge. In them self, they do not contribute to learn since they merely put the student in an environment where practice is possible.

\section{e. Management and Planning}

In addition, management and planning are also can be categorized as learning strategies. These strategies are related with the learner's intention to direct his own learning. A learner can take charge of the development of his own program when he is helped by a teacher whose role is that of an 
adviser and resource person. That is to say that the learner must:

1. Decide what commitment to make to language learning

2. Set himself reasonable goals

3. Decide on an appropriate methodology, select appropriate resources, and monitor progress,

4. Evaluate his achievement in the light of previously determined goals and expectations.

More clearly, Chamot and O' Malley, and Oxford in Nunan (2003) Classified the learning strategies in the following table:

\begin{tabular}{c|l}
\hline $\begin{array}{c}\text { Learning } \\
\text { Strategy }\end{array}$ & \multicolumn{1}{|c}{ Definition of Strategy } \\
\hline Metacognitive Strategies \\
\hline Planning & $\begin{array}{l}\text { Preview main idea } \\
\text { Making plans to accomplish a } \\
\text { task } \\
\text { Paying attention top the key } \\
\text { information } \\
\text { Seeking out and arranging for } \\
\text { conditions to } \\
\text { promote successful learning }\end{array}$ \\
\hline Monitoring & $\begin{array}{l}\text { Self Checking ones } \\
\text { comprehension }\end{array}$ \\
\hline Evaluating & $\begin{array}{l}\text { Developing the ability to } \\
\text { determine how well one has } \\
\text { accomplished the task }\end{array}$ \\
\hline Cognitive Strat
\end{tabular}

\begin{tabular}{l|l}
\hline Cognitive Strategies \\
\hline Summarizing & $\begin{array}{l}\text { Saying or writing } \\
\text { the Main idea }\end{array}$ \\
\hline Induction & $\begin{array}{l}\text { Figuring out the rules from } \\
\text { samples of language }\end{array}$ \\
\hline Imagery & $\begin{array}{l}\text { Being able to visualize a picture } \\
\text { and use it to learn new } \\
\text { information }\end{array}$ \\
\hline $\begin{array}{l}\text { Auditory } \\
\text { representatio } \\
\text { n }\end{array}$ & $\begin{array}{l}\text { Mentally replaying a word, } \\
\text { phrase or peace of information }\end{array}$ \\
\hline $\begin{array}{l}\text { Making } \\
\text { inference }\end{array}$ & $\begin{array}{l}\text { Using information in the text to } \\
\text { guess the meaning }\end{array}$ \\
\hline Using & $\begin{array}{l}\text { Developing the ability to use } \\
\text { reference material }\end{array}$ \\
\hline resources & $\begin{array}{l}\text { Classifying } \\
\text { terminologies, quantities, or } \\
\text { concepts }\end{array}$ \\
\hline Note- Taking & Writing down key words and \\
\hline
\end{tabular}

\begin{tabular}{l|l}
\hline & $\begin{array}{l}\text { loncepts in verbal graphic, or } \\
\text { numerical forms }\end{array}$ \\
\hline $\begin{array}{l}\text { Elaborating } \\
\text { of Prior } \\
\text { knowledge }\end{array}$ & $\begin{array}{l}\text { Relating new to information and } \\
\text { making personal association }\end{array}$ \\
\hline Social Affective Strategies \\
\hline Cooperating & $\begin{array}{l}\text { Learning how to work with } \\
\text { peers-completing a task, } \\
\text { pooling information, solving a } \\
\text { problem, and obtaining feedback }\end{array}$ \\
\hline Clarifying & $\begin{array}{l}\text { Learning how to ask question } \\
\text { how to get additional } \\
\text { explanations, or verifying from } \\
\text { the teacher or someone else who } \\
\text { might know the answer }\end{array}$ \\
\hline Self- Talk & $\begin{array}{l}\text { Reducing anxiety by talking } \\
\text { positively to one self }\end{array}$ \\
\hline
\end{tabular}

Basically, those five categorizations of the learning strategies can be condensed into three. They are cognitive, metacognitive and social strategies.

\section{SPEAKING}

Speaking means to say words (Oxford: 1987). When doing this, a person uses his brain and arbitrary organs to say the words or the utterance. Through the activities, the speaker's purpose is to deliver meaning to the person whom he is talking to.

\section{Basic types of Speaking}

Brown (2004: 141) categorized the basic types of speaking as follows:

\section{a. Imitative}

At one end of continuum of types of speaking performance is the ability to simply parrot back (imitate) a word or phrase or possibly sentence. While this purely phonetic level of oral production, a number of prosodic, lexical, and grammatical properties of languages may be included in the criterion performance.

\section{b. Intensive}

The second types of speaking frequently employ and assessment context is the production of short stretches of oral language designed to demonstrate commencer in a narrow band of grammatical, phrasal, lexical and phonological relationship 
such as prosodic elements--intonation, stress, rhythm, and juncture.

\section{c. Responsive}

Responsive assessment task include interaction and test comprehension but at the somewhat limited level of very short conversation, standard greeting and small talks, simple request, and comet and the like.

\section{d. Extensive (monologue)}

Extensive oral production task include speech oral presentation, storytelling, during which the opportunity for oral interaction from listener is either highly limited (perhaps to nonverbal responses) or rolled out altogether.

So those types speaking activities are much concern with the age of the speaker. A speaker will be able to produce the more complicated sentences as he become older.

\section{Types of Learning Strategies in Speaking}

According to Kennedy and Keatley (2006), the following strategies can help the language learner to develop their speaking skills.

\section{a. Using minimal responses}

Language learners who lack confidence in their ability to participate successfully in oral interaction often listen in silence while others do the talking. One way to encourage such learners to begin to participate is to help them build up a stock of minimal responses that they can use in different types of exchanges. Such responses can be especially useful for beginners.

\section{b. Recognizing scripts}

Some communication situations are associated with a predictable set of spoken exchanges a script. Greetings, apologies, compliments, invitations, and other functions that are influenced by social and cultural norms often follow patterns or scripts. So do the transactional exchanges involved in activities such as obtaining information and making a purchase. In these scripts, the relationship between a speaker's turn and the one that follows it can often be anticipated.

\section{c. Using language to talk about language}

Language learners are often too embarrassed or shy to say anything when they do not understand another speaker or when they realize that a conversation partner has not understood them. Instructors can help students overcome this reticence by assuring them that misunderstanding and the need for clarification can occur in any type of interaction, whatever the participants' language skill levels. Instructors can also give students strategies and phrases to use for clarification and comprehension check.

In other side Houang (2006) also formulates the following activities that he considered good in learning a language. They are

\begin{tabular}{l|l}
\hline \multicolumn{1}{c|}{ Strategy } & \multicolumn{1}{|c}{ Description } \\
\hline Imitation & $\begin{array}{l}\text { Observing the teacher, native } \\
\text { speaker or the models then } \\
\text { imitating }\end{array}$ \\
\hline Technical means & $\begin{array}{l}\text { Using the technical means like } \\
\text { tape recorder, video, .. to } \\
\text { learn, store or practice the } \\
\text { language }\end{array}$ \\
\hline Practicing alone & $\begin{array}{l}\text { Talking to self, answering to } \\
\text { self question, and creating } \\
\text { situation to practice in your } \\
\text { own. }\end{array}$ \\
\hline Question & $\begin{array}{l}\text { Asking a teacher, native } \\
\text { speaker, etc... for repetition, } \\
\text { paraphrasing, explanation and/ } \\
\text { or example }\end{array}$ \\
\hline Communication & $\begin{array}{l}\text { Creating opportunities to } \\
\text { practice the language by } \\
\text { making conversation with } \\
\text { native speaker or foreigner or } \\
\text { those who speak English. }\end{array}$ \\
\hline Self monitoring & $\begin{array}{l}\text { Correcting your speech for } \\
\text { accuracy or appropriateness to } \\
\text { context }\end{array}$ \\
\hline Self evaluation & $\begin{array}{l}\text { Always checking learning } \\
\text { outcome against internal } \\
\text { standard }\end{array}$ \\
$\begin{array}{l}\text { Repeating a language model } \\
\text { including overt practice and } \\
\text { silent rehearsal or repeating } \\
\text { the name of items, or object } \\
\text { that had been heard }\end{array}$ \\
\hline
\end{tabular}

There are still so many types of learning speaking strategies that can be used by the students. Obtaining Cassette recording of the 
dialogues that will aid the fluency and the intonation, talk to one self ask and answer by himself, find a symphatic friend with whom the student can practice regularly, try to make the learning become a more enjoyable activities like having same games, storytelling, seeking out native speaker, hold an imaginary conversation, using diaries to monitor, imitating the way native speaker speak form TV and song, Creating English drama, Visit the English teacher, Evaluation progress, and so on (from many sources).

Each strategy needs planning, management and evaluation. Therefore, cognitive, metacognitive social and communication strategies must be collaborated to get good outcome. But the learner can also make his or her own ways in learning.

\section{READING}

Reading is the process of transferring idea through verbal symbol from the writer to the reader. Harmer (1981: 153) defines reading as exercise dominated by the eyes and the brain. The eyes receive the message and the brain has to work out the significances of these messages.

\section{Types of Reading Strategies}

Kennedy and Keatley (2006) formulate strategies that can help students read more quickly and effectively include:

a. Previewing: reviewing titles, section headings, and photo captions to get a sense of the structure and content of a reading selection.

b. Predicting: using knowledge of the subject matter to make predictions about content and vocabulary and check comprehension; using knowledge of the text type and purpose to make predictions about discourse structure; using knowledge about the author to make predictions about writing style, vocabulary, and content.

c. Skimming and scanning: using a quick survey of the text to get the main idea, identify text structure, confirm or question predictions.

d. Guessing from context: using prior knowledge of the subject and the ideas in the text as clues to the meanings of unknown words, instead of stopping to look them up.

e. Paraphrasing: stopping at the end of a section to check comprehension by restating the information and ideas in the text.

f. In addition, Longwood (2006) suggest the following strategies in reading:

g. First skim: read for the gist, not for details. Guess at meanings, based on the context, and try to get a general idea. Take into account any pictures, titles, subtitles and format.

h. Think about what you already know about the topic. Bringing to mind concepts that may have something to do with what you are reading will help you to understand more.

i. Assume that cognates mean what they look like (although they don't

always). Guess. Guessing is good, if it is based on things like the context, what you already know about the topic, the part of speech, etc

j. Skip words you don't understand. (Skipping is good; guessing is good.)

k. Predict and revise your predictions about what is going to occur in the reading. Those types of reading strategies can guide the student to improve their reading skill. But, using sources like English newspaper, magazine journal or other sources also can be categorized as reading strategies.

\section{RELATED FINDINGS}

Kustati (2003) in her research, Students Speaking-Related Language Learning Strategies in their Speaking Ability, she found that there are thirty four speaking related LLS which most frequently used by high average, and low achievement student. It was also found that practicing naturally and using circumlocution and synonym are the highest intensity of speaking related LLS used by the students in speaking. In 2004, Liu conducted Research under the title "EFL Proficiency, Gender And Language Learning Strategy Use Among A Group Of Chinese Technological Institute English Majors". Descriptive statistics indicated 
that the Chinese technological institute English majors were medium strategy users (Overall strategy use $\mathrm{M}=3.25, \mathrm{SD}=.53$ ); the most frequently used strategies were Metacognitive strategies $(\mathrm{M}=3.74, \mathrm{SD}=.64)$ and the least frequently used were Memory strategies $(\mathrm{M}=2.91, \mathrm{SD}=.61)$. Nadrah (2004) also had her research under the title "The Contribution of Reading Strategies and Vocabulary Mastery to Reading Comprehension". Her research was aimed to describe the contribution of reading strategies and vocabulary mastery toward reading comprehension. This research found that the reading strategies and vocabulary mastery had significant contribution to reading comprehension. Then, a research that had been conducted by Idrus, Communication and Social Strategies of Successful English Learners At PT Semen Padang (2005) conclude that the social communication strategies applied by the 20 subjects provide them with what can be called a mini English speaking Community. The interaction in the community and Teacher Teaching Strategies gave them sufficient input and to develop and maintain their English proficiency than enable them to successfully communicate with the native speakers expatiates from other countries. Third, Ozek (2006) in his study, "A Study on the Use of Cognitive Reading Strategies by ELT Students. The results of TAPs analysis revealed that the students used only one strategy namely, "relating the title to the text content" in the prereading phase. As for the while-reading phase, the most effectively employed strategies were: using the dictionary parsimoniously, guessing the meaning of a word from the context, skipping some unknown words, thinking-aloud during reading, and assimilating the text with the background knowledge

In 2006 Volya conducted a research, Student Speaking Strategies and teacher Teaching Speaking Strategies at Senior high school in Kerinci District. She found that there were a number of strategies found in speaking encountered at senior High school in Kerinci District. The strategies were speaking with friends, Speaking with English Teacher, Trying to find English Speaker, and talking to themselves in English, taking English course, making dialogues, listening English music and watching English movie, Those strategies were perceived, believed, regarded, though and considered differently by the students.

The related findings above tried to identify the influence of learning strategies in the students' speaking ability, Communication and Social Strategies of Successful English Learners and also identifying the students' speaking strategies and the teacher teaching strategies at level of high school, the contribution of reading strategies and vocabulary mastery to reading comprehension, the contribution of reading strategies and vocabulary mastery to reading comprehension and study on the use of cognitive reading strategies by ELT students. Differently, this research found the three classifications of learning strategies in reading and speaking; metacognitive, cognitive and social strategies at once that being used by the English department students.

\section{POPULATION AND SAMPLE}

The population of this research was the third year students (Pre-Serve Teacher) of English Department, Faculty of Teacher Training and Education Bung Hatta University in academic year of 2004 that consisted of 75 students or three classes. As the sample, the researcher took the total of the population. He took this academic year because the students have been learning speaking and reading in the academic level for 3 years. Beside this reason, they also can be assumed able to find, to choose, to create and manage their own learning strategies. Descriptive data are usually collected by questionnaire, interview, telephone, or observation (Gay and Airasian: 2000). In this research, the data were collected through interview, questionnaire, and observation. First, researcher gathered the students. Here, the researcher gave instructions, and then he distributed the questioner to the students. To get more information, he also did interview with some guide line. Finally, observation was also needed to complete the data that he had got. During his observation, the researcher took some notes to get the expected information, and 
had some checklist of what was happening or what strategies that had the students done.

Since the data consisted of numerical data and the some recorded data, the researcher used mixing method (combining quantitative and qualitative method to analyze he data.

Moleong in Ismael (2004) formulate the following steps to analyze the types of data. The steps are:

1. Utilizing: To read and learn data that was collected. Then, all units were identified carefully. Then, the data were taken into the index.

2. Categorizing: To arrange the category file and. In this analysis, the researcher classified the leaning strategies used by the English Department students into three parts, metacognitive, cognitive and social strategies.

3. Interpreting: Data interpretation is classified to; aim, general, function of relationship, function of data, interrogation and steps of data interpreting by using comparative analysis.

4. To determine the profile of the student learning strategies, the researcher used the following steps:

a. To divide the strategies become six parts: cognitive, metacognitive and social learning strategies in speaking; cognitive, metacognitive and social learning strategies in reading.

b. To count the score by giving 5 for those who answer always, 4 for usually,

3 for sometime, 2 for rare, and 1 for those who answer never.

\section{INSTRUMENTATION}

Learning Strategies are observable and unobservable. It means that some of learning strategies are in the form of the mental process that happening in leaner brain. There is no specific tool used to identify types of the student learning strategies. But, in some previous years some researcher use questioners to know the learning strategies used by the students. In this research, the researcher use questionnaire that consists of 40 items that concern with cognitive, metacognitive and social /earning strategies in reading and speaking. The questionnaire is based on SILL (Strategy Inventory Language Learning) that created by Oxford with some modification that had been made. Beside the questionnaire, the researcher also used some guideline to help him to interview the students. Then, to support the data from the interview and the questionnaire, some observation guidelines were also used to help him to find the information that he need

To determine the profile of the student's learning strategies, the researcher

count and found the total average of each strategy. In general, it can be described in the following chart. (Mean score)



Chat 1

Based on the chart above, it can be summarized that the English department have medium score in all of learning strategies both in speaking and reading. This mean score is based on the following categories:

\begin{tabular}{l|l|l}
\hline High & $\begin{array}{l}\text { Always or almost } \\
\text { always used } \\
\text { Usually Used }\end{array}$ & $\begin{array}{l}4.5 \text { to } 5.0 \\
3.5 \text { to } 4\end{array}$ \\
\hline Medium & Sometime used & $\begin{array}{l}2.5 \text { to } 3.4 \\
1.5 \text { to } 2.4\end{array}$ \\
\hline Low & Generally not used & 1.0 to 1.4 \\
& Never or almost & \\
& never used & \\
\hline
\end{tabular}

(Categorized by oxford, 1994) 


\section{FINDINGS}

The distribution of cognitive learning strategies in speaking used by the student of English Department indicate that the overall student have medium level. The same condition can be seen almost the same with what Liu found in 2004. He found that the Chinese technological institute English majors were medium strategy users (Overall strategy use M $=3.25, \mathrm{SD}=.53)$; the most frequently used strategies were Metacognitive strategies (M $=3.74, \mathrm{SD}=.64)$ and the least frequently used were Memory strategies $(\mathrm{M}=2.91, \mathrm{SD}=.61)$. As what oxford (1990: 43) say that cognitive learning strategy is essential in learning a new language. This is the mental process that a learner has when he is learning. It can be assure that if the cognitive learning strategies especially in speaking do not apply as well, the result of the language learning will not raise the outcome.

Related to the cognitive learning strategies, students must have and apply metacognitive learning strategy to control, to manage, and evaluate the process of the language learning. However, it was found that the level of the mean score of the student for this strategy is also medium (3.06). Similarly, with what had been found in cognitive learning strategies in speaking, it was found that there are still many of them rare and sometime to apply the metacognitive learning strategies.

Then, is not too surprising that the level of social learning strategies in speaking was also medium with the mean score 3.16. Volya (2006) found almost the same finding related to the types of social learning strategies that found in this research. They were speaking with friends, speaking with English teacher, trying to find English speaker, and talking to themselves in English, taking English course, making dialogues, listening English music and watching English movie (compare with conclusion).

There were only a few of them who keep to practice their English especially speaking skill by using their social environment like with their lecturer, their sympathy friends, native speaker or even trying to talk with them self. However language is a social skill. Thus, they must take a part to use English as many as possible with their social community.

In reading, the same condition also occurred. The level cognitive learning strategies in reading was also medium with the total mean score 3.13. Some of the learning strategies in reading were also the same with what Ozek (2006) found. The strategies were: using the dictionary parsimoniously, guessing the meaning of a word from the context, skipping some unknown words, thinking-aloud during reading, and assimilating the text with the background knowledge. But, the different is that this research includes using sources or other reading materials like reading magazine and newspaper as the part the cognitive learning strategies in reading.

However the student's answer shows that most of them answer "sometime" related to the questionnaire about metacognitive learning strategies in reading. Wenden and Rubin (1987: 25) state that this strategy are used to oversee, regulate or self - directed language learning. The strategies are used to control, to manage and to evaluate (metacognitive learning strategy) the students have also can be categorized as medium. As a matter of a fact, the mean score was 3.04 .

Finally, the result in the findings also inform that the level of the social learning strategies of the student in reading is also medium with the mean score 3.01 (the least score). It is different with speaking, reading do not require much social learning strategies since most of reading activities are done without cooperation with others.

It was also can be interpreted that one strategies can influence other strategies in one skill or even can contribute strategies in others skill. For example, the more cognitive learning strategies in speaking done by the student, the more students do the metacognitive and social learning strategies. A student first will imitate the way native speaker or the way their lecture speak. Then, he can apply or repeat it when he speaks with other person (social learning strategies). The contradicted condition also can occur if the students do more metacognitive learning strategies. Logically, the more students manage, evaluate and control their learning 
practice, the more they do the cognitive and social learning strategies.

\section{CONCLUSION}

It is concluded that he existing cognitive, metacognitive and social learning strategy both in reading and speaking of the student of English department of Pre-Served Teacher, Faculty of Teacher Training and Education are medium. Also, it was found that the cognitive, metacognitive, and social learning strategy are interrelated one to others. The decision maker can make or review the curriculum to be a guideline for the next curriculum planning. The curriculum should be based much on the learning process way. The English Department may create or improve some courses that will more focus of learning in the process of the English instructions. It can also facilitate the learning by providing various types of learning materials that can be used in learning process.

\section{REFERENCE}

Brown, H.D: 2004. Language Assessment Principles and Classroom Practice. San Francisco: Francisco State Universities.

Chamot, et all. 1999. The Learning Strategies Handbook. New York: Longman.

Fedderholdt, Karen. 2006. The Language Teacher Using Diaries to Develop Language Learning Strategies. Retrieved on April 2006 from Error! Hyperlink reference not valid. www, $j$ alt-puibl ication-org/tit/fi le98/fedderhold.html.

Ellis, R. 1994. The Study of Second Language Acquisition. Oxford: Oxford University Press.

Harmer, J. 1984. The practice of English Language: Handbook of language Teaching. London: Longman

Hismanoglu, Murat.2007. Language Learning Strategies in Foreign Language Learning and Teaching. Retrieved on 21 January 2007 from http://iteslj.org/Articles/Hismanoglu-

Strategies.html.

Hoang, Le Thanh. 2006 Research into language learning strategies of different groups of learners in Hue City, retreived on 17 mei 2006 from http/wwwlanguage. alt, ac. th/Hcmoi-proceding/ithoanghtm.

Hornby, A.S. 1995. Oxford Advanced Learner's dictionary of Current English. NY: Oxford University Press.

ldrus,Rusdayati. 2005 Communication and Social Strategies of Succesful English Learners at PT Semen. Padang: Padang State University.

Ismael Syamsuardi. 2004 English Learning Strategies used by the Third Year Students of SMA LI Padang. Padang. Padang State University.

Kennedy and Keatley. 2006. Motivating LearnersAchieving Success with Learning Strategies. retrieved on 2 June 2006. from http://www.nclrc.org/essentials/motivati ng/strategies.htm.

Kennedy and Keatley. 2006. Teaching Reading Strategies for Developing Reading Skill, retrieved on 2 June 2006. from http://www.nclrc.org/essentials/motivati ng/strategies.htm.

Kustati, Martini. 2003. Students Speaking Related Language Learning Strategies in their speaking Ability. Padang: Padang State University

Lessard, Michael and Clouston. 1997. Language Learning Strategies; An Overview for L2 Teachers. Japan: Kwansei Gakuin University.

Liu, Dongyue. 2004. EFL Proficiency, Gender And Language Learning Strategy Use Among A Group Of Chinese Technological Institute English Majors, retrieved on 2 January 2006. from http://www.ecls.ncl.ac.uk/publish/Volum e 1/Dongyue/Dongyue.htm.

Longwood.2006. Strategies for Learning a Foreign Language. Retrieved on 29 April 2006. Error! Hyperlink reference not valid..

Nadrah. 2004. The contribution of Reading Strategiesn and vocabulary mastery to Reading Conprehension. (Unpublished Thesis). Padang: Padang State University. 
Nunan, David. 2003. Practical English Language Teaching. Boston: Mac Graw Hill.

O'Malley, JM., Chamot, A.U. I990. Learning Strategies in Second Language Acquisition. New York: Cambridge University Press.

Oxford, Rebecca. 1994. Language Learning Strategies: An Update. Retrieve on 29 may 2007. from http://www.cal.org/resources/digest/oxfo rd01.html. , 1990. Language Learning Strategies. What every Teacher Should Know. New York: Newbury House Publisher.

Ozek, Yesim. 2006. A Study on the Use of Cognitive Reading Strategies by ELT
Students. Retrieve on 2 may 2007. from http://www.asian-efljournal.com/pta_august_07_ozec.php.

Rubin, Joan and Irene Thomson. 1982. How to a Better Language Learner: How to Be a more Successful Language Learner. Boston: Heinle \& Heinle Publisher.

Rubin, J. 1975. What the Good Language Learner Can Teach Us. TESOL. Quarterly. 9.

Wenden, Anita and Joan Rubin. 1987. Learner Strategies in Language Learning. London: Prentice Hall international Ltd.

Zainil, 2005. Good language Learner Strategies and Communicative Language Teaching. Padang: Padang State University Press. 